\title{
THE WAYS OF INCREASING THE AMOUNT OF STUDENTS ' STUDY TIME FOR MASTERING A FOREIGN LANGUAGE IN A NON-LINGUISTIC UNIVERSITY
}

\author{
Ermakova Lyubov A. \\ Professor, \\ Department of Foreign Languages, \\ Russian State University for the Humanities, \\ Moscow, Russia
}

\begin{abstract}
The article attempts to analyse the most possible and effective options for increasing the amount of study time allocated to students and by the students themselves for mastering a foreign language in a non-linguistic university. To achieve this goal the author proposes to reconsider and reform the format of students' independent work, making it a full-fledged component of a continuous interactive educational process.

The practical value of the transition to teaching basic and specialized subjects in a foreign language is also emphasized through additional qualifications of the teaching staff, their active creative interaction, as well as high-quality training of students based on the school curriculum. The author calls the third way to expand the time frame for mastering a foreign language to actively introduce the formats of game and project activities into the educational process.

Key words: independent work of students; distance learning format; efficiency; motivation; quality of education; global game
\end{abstract}

\section{Introduction}

The current situation with the constant reduction of full-time classroom hours allocated to students for studying a foreign language is also aggravated by the global cataclysm - a pandemic - which "drives" students and teachers into remote mode. Distance learning, in turn, has a number of obvious disadvantages in comparison with full-time classes.

"Against the background of all these unfavorable conditions for learning (and especially mastering "from scratch") a foreign language, all possible options should be considered to improve the quality of teaching a foreign language in a nonlinguistic university" $[5,26]$.

According to the author, among the most possible and feasible options for maintaining (and even improving) the conditions for teaching foreign languages, as well as the quality of language acquisition by students, are the following:

1. Rationalization and optimization of the approach to the organization and monitoring of students' independent work. This option will allow you to:

1) increase the amount of time spent on language learning at times;

2) give students the opportunity to productively allocate time to study;

3) motivate students to master the course program and even go beyond it.

2. Gradual transition to teaching some specialized disciplines in a foreign language. We are talking about full-fledged courses conducted by teachers of a foreign language who also have a specialized education in the discipline taught.

3. Development of project activities of students, allowing a large percentage of independent training and a small number of full-time or even remote hours for control and verification.

Now let's consider all three of these options for optimizing and updating the educational process in more detail.

Rethinking the role of independent work of students in the process of teaching a foreign language in a nonlinguistic university.

It's no secret that learning the basics of a foreign language (and mastering it) is not an easy task. Whether we like it or not, the current situation in society challenges foreign language teachers to compensate for the lack of face-to-face classroom communication between teachers and students through a rational approach to organizing and monitoring the process of independent work of students.

Speaking about a new approach to independent work, the author does not attempt to reduce the entire educational process to the already existing formats of full-time and part-time education. The latter also assume a predominant share of independent training of students and a minimum number of classroom hours for final control and evaluation. In contrast to these two learning formats, the optimized format of students' independent work should be an integral component of the continuous contact and cooperation of the teacher and students throughout the entire training course. Thus, even when performing tasks independently, students should not have the impression of a certain isolation from the group, the course and the teacher. Let's consider some important changes that should be made to the format of independent work of students, so that it can become a full-fledged part of the continuous interaction of the teacher and their students. 
1. According to the author, one of the most important conditions for the future successful work of students in the format of independent training should be the first introductory meeting of the course. It is there that the emotional contact between the teacher and the students takes place, which is designed to provide the latter with motivation for productive autonomous creativity when the teacher is "not around". A properly structured dialogue at the first meeting should not only formulate a clear understanding of the course structure, the elements of certification and final control, but also, much more importantly, create a positive working atmosphere that will extend throughout the course.

Ideally, students should feel like members of a unified team and "recognize" the teacher as their leader. Team spirit and a sense of responsibility for the overall success (after all, it is the maximum desired result of the course) will help to increase the motivation of each student and the group as a whole. For more information about the importance of student motivation and the various ways to achieve it, see the article by V.I. Uvarov "The problem of student motivation in the educational process and possible strategies for its solution" [10, 63-68].

2. Provided that a positive contact is established between the teacher and the students, as well as the creation of a long-term emotional atmosphere of involvement in the educational process, independent work of students can take place without constant monitoring by the teacher. But, if we expect to get the maximum performance at the end of the course, the teacher must be present throughout the independent work of students with the educational material. As mentioned earlier, the periodic autonomous work of students can expand the scope of academic time devoted to the discipline.

However, it is also not necessary to overload students, giving them an excessive amount of material for independent training. In order to eliminate the overload of students in the offline mode and to determine the optimal (but much broader than with a conservative approach to independent work) time frame, teachers themselves must pass the course offered to the students, taking into account their personal characteristics and leaving opportunities for adaptive changes.

3. Speaking about the advantages of a well-thought-out organization of independent work of students, one more important circumstance should be noted, namely, the ability to take into account the personal qualities and capabilities of each student of the study group. Thus, a student who is motivated to achieve a result and clearly understands the structure of the course (and each individual module) can independently regulate the activity of their educational activities within the framework provided for by the course program. For example, if some students complete a specific module of tasks faster than the "standard", they have an alternative: to start the next module or to rest. The main quality of such autonomous work is the manifestation of awareness and responsibility on the part of students, provided by the correct approach to their independent work, which was discussed above.

\section{Teaching some specialized disciplines in a foreign language.}

The second most effective way, according to the author, to significantly increase the study time for learning a foreign language in a non-linguistic university can be a gradual transition from teaching basic and specialized subjects in their native language to submitting material in a foreign language. This will increase the time of students' language practice many times.

Ideally, a specialized subject should be taught by a teacher who has a corresponding higher education and is fluent in a general and specialized foreign language. Of course, such a transition is almost impossible in a short time, since:

1) at the moment not all teachers meet the requirement of professional proficiency in actually two disciplines (language plus a specialized subject);

2) the level of students does not always correspond to the minimum required for the development of disciplines in a foreign language;

3 ) it takes time to develop new training programs and compile a database of training content.

The transition to teaching university subjects in a foreign language should involve preliminary training not only for teachers (for example, in the form of advanced training courses), but, more importantly, for students themselves. This task should be carried out by the school, which also requires a reform process.

At the intermediate stage of the transition to teaching basic and specialized subjects in a non-linguistic university, the author suggests actively using the creative interaction of teachers of specialized subjects and teachers of a foreign language. The joint cooperation of two professional teachers in their respective fields opens up a wide range of opportunities for high-quality preparation for the transition of the educational process to a new format.

\section{Project activity as an ideal format for independent work of students.}

The above-mentioned opportunities for a significant increase in students' study time for mastering a foreign language in a non-linguistic university can be implemented in the most optimal, according to the author, format of training for these purposes - project activities. At the same time, we are not talking about endless boring reports or presentations that give little return in terms of the formation of students' language competence solely due to their excessive number and uniformity of presentation of the material.

"The introduction of game technology can help to make learning a foreign language much more attractive for students and, most importantly, more effective and up-to-date" [4, 109]. The author calls the process of teaching a foreign language with the overwhelming share of independent work of students, which is a symbiosis of project activities and games, a "global game". "In a very simplified form, the "global game" is a chain of logically interconnected cases leading to a certain "final". The global game may be particularly relevant in the process of teaching students the language of their specialty, that is, in the language environment in which they will work after graduation. " $[4,109]$ 
In the context of distance learning, the global game format fits perfectly into the educational process, where students prepare for each module independently (using the teacher's instructions and feeling constant monitoring of the process), and its implementation - in the form of meetings in online mode (in the format of a case, role-playing game, round table, conference, competition of creative projects, etc.).

In addition, an interesting format and a well-thought-out scenario will make it possible to interest students and, thereby, "force" them to "voluntarily" and sincerely devote maximum time to mastering a foreign language, strive for the best result, that is, successful completion of the training course.

\section{Conclusion}

According to the author, the current situation in the modern world with the pandemic and the accompanying modes of distancing and self-isolation gives the educational community an opportunity to take a fresh look at previously underestimated formats of organizing the educational process, such as the autonomous work of students, which is an integral part of the continuous interaction between teachers and students.

This approach to independent work of students, as well as the expansion of the platform for mastering and practicing a foreign language (on the basis of teaching specialized disciplines) in symbiotic interaction with modern formats of game and project activities, is designed, to our mind, to significantly increase the amount of educational time allocated to a foreign language, even in a non-linguistic university.

\section{References}

1. Egorychev A.M., Fedoseeva I. A. The concept of management of the education system in a modern higher educational institution on the basis of a synergetic approach // Bulletin of Economic Integration. 2012. - № 8 (52). - pp. 167-173. URL: https://elibrary.ru/item.asp?id=18726411

2. Organization and control of independent work of students: methodological recommendations / comp. N. V. Solovova; ed. by V. P. Garkin. - Samara: Publishing house "Univers-group". 2006. - P. 15.

3. Pak Yu. N., Shilnikova I. O., Pak D. Yu. Independent work of the student in the conditions of the state educational system of the new generation // Higher education in Russia. 2015. - No. 6. - pp. 138-144. URL: https://elibrary.ru/item.asp?id=23929728

4. Uvarov V. I. The concept of a global game in teaching students a foreign language // Bulletin of the RSUH. Series " Psychology. Pedagogy. Education". 2019. - No. 3. - pp. 107-115. URL: https://elibrary.ru/item.asp?id=41125317

5. Fedoseeva I. A. On the question of the quality of higher education in modern Russian society.. 2016. - № 3 (7). P. 26. URL: https://elibrary.ru/item.asp?id=26398867

6. Fedoseeva I. A. Theoretical approaches to building a strategy for the development of higher education // Social pedagogy. 2015. - No. 1. - pp. 71-75. URL:https://elibrary.ru/item.asp?id=23602025

7. Fomina S. N., Bereza N. A., Kvitkovskaya A. A. Building an individual educational route of a student as a way of conscious educational activity // Uchenye zapiski Rossiyskogo gosudarstvennogo sotsialnogo universiteta. 2018. - Vol. 17. - № 3 (148). - PP. 42-49. URL: https://elibrary.ru/item.asp?id=36499780

8. Khokhoeva L. V. The role of independent work in the formation of academic competencies. Vektor nauki TSU. 2012. - № 4 (11). - pp. 314-317. URL: https://elibrary.ru/item.asp?id=18755583

9. Shcherbakova E. V. Independent work of students as the most important component of the organization of the educational process in the university. 2010. - No. 8. - Vol. 2. - P. 188-190. URL https://elibrary.ru/item.asp?id=15173169

10. Uvarov VI. The problem of motivation of students within the educational process and possible strategies for its solution // Materials of the International Conference "Scientific research of the SCO countries: synergy and integration" Reports in English. Part 3 (August 31, 2019. Beijing, PRC) - pp. 63-68. ISBN 978-5-905695-51-3 